\title{
Fish Corral Composition, Abundance, and Distribution in the Reef Flat of Palompon, Leyte, Philippines
}

\author{
Jerome Benedict P. Cabansag ${ }^{1}$, Arriane Krisna Rose T. Tuazon ${ }^{1}$, and \\ Liezel C. Paraboles ${ }^{2}$
}

${ }^{1}$ Division of Natural Sciences and Mathematics, University of the Philippines Visayas Tacloban College, Magsaysay Boulevard, Tacloban City, Philippines 6500;

${ }^{2}$ Oceanbio Laboratory., Division of Biological Sciences, College of Arts and

Sciences. University of the Philippines Visayas. Miag-ao, Iloilo 5023

\begin{abstract}
There is paucity of studies relating to fish corral fishery and its management particularly those operated on reef flats. This study was conducted to evaluate the fish catch composition of fish corrals situated in the reef flat of Palompon, Leyte from July 2009 to January 2010. During the monitoring, two sets of data were utilized: the semimonthly field intercept samplings and the daily fish landing data. Field intercept samplings enabled the researchers to approach fishers as they were gathering their fish catch that was eventually identified, sorted, measured, and weighed. Fish landing data recorded by local enumerators included the fish's local name and corresponding weight. From 27 fish corrals, the intercept samplings yielded a total catch of $23.9 \mathrm{~kg}$, which was composed of 81 identified species under 47 genera from 31 families. The most abundant family was Siganidae comprising $44 \%$ of the total catch, followed by Apogonidae (18\%) and Pomacentridae (9\%). This composition was corroborated by the fish landed data. The temporal and spatial trends of the catch composition showed that Fam. Siganidae was most abundant in the months of July, October, and December, while Apogonidae in the months of August and November. It was observed that there was an unequal spatial distribution of fish species in the study area. Of the four sampling areas, Area 2 on the northeastern part of Palompon was the most diverse due partly to the high number of fish corral units and the area's structural complexity wherein seagrass and algal beds were most extensive interspersed with coral patches. Results of this study could serve as reference for future studies dealing with monitoring and managing fish corral fishery.
\end{abstract}

Keywords: Reef flat, fish corral, spatial distribution, temporal distribution

Correspondence: Jerome Benedict P. Cabansag Address: Division of Natural Sciences and Mathematics, University of the Philippines, Visayas Tacloban College, Magsaysay Boulevard, Tacloban City, Philippines 6500 Email: jeromebpc@yahoo.com Tel/Fax: +6353 3218299

DOI: $10.32945 /$ atr3324.2011 


\section{INTRODUCTION}

Coastal municipalities throughout the Philippines have high dependence on fish corrals. Fish corrals usually rank second when it comes to the number of gear units found in the area, i.e. among gears that play a big part in the annual fish catch of the area (Mercene and Nasino, 1994).

In Palompon, the municipal fishery registry has recorded 64 fish corral units. Palompon is a second class coastal municipality situated at the midwestern coast of Leyte at $11^{\circ} 05^{\prime} \mathrm{N}$ latitude and $124^{\circ} 38^{\prime} \mathrm{E}$ longitude. It is bounded by Villaba and Matag-ob on the north, Merida on the east, Isabel on the south, and Camotes Sea and Ormoc City on the west.

Like other coastal municipalities, fishing industry is one of Palompon's major sources of livelihood. As with other coastal artisanal fishery in the country, it is generally complex because it is multigear and exploitatively multispecies (Maneja and Hilomen, 2008; Mercene and Nasino, 1994).

Fish corrals in Palompon are set fishing method and operate throughout the year, whereas, these operate only during certain months in other municipalities (Supanga and Smith, 1994). In Palompon, however, such operation excludes a four-day period immediately following the onset of the new moon phase in the months of February, March, and April, (V. Selpa, Pers. Comm., December 22, 2009). This 'closed season' is being done to regulate the catch of rabbitfishes (Fam. Siganidae) allowing them to migrate in the area, especially in these months where the aggregation of the said fish group is at its peak.

Despite the known importance of fish corrals in the fishing industry, few studies had been done on fish corral's economic contributions (e.g. Calud et al., 1989; Robinson et al., 2004; Supanga and Smith, 1994) and on trending of the fish catch across time (e.g. McClanahan, 1988; Soliman et al., 2008). Consultation among some Palompon fish corral owners revealed that there is a significant decrease in fish catch through time. This claim further necessitates the importance of fishery monitoring that contributes to fishery management of the area.

This paper presents the baseline data of the Palompon fish corral fishery. Specifically, this study aims to: (1) generate catch composition profile that includes species diversity and abundance; (2) evaluate the spatial and temporal variation of the catch composition; and (3) complete 
any variation in the physico-chemical parameters of the study site with the variation in catch composition of the fish corrals.

\section{MATERIALS AND METHODS}

Study Area

The study was conducted on the $48,550 \mathrm{~km}^{2}$ reef flat situated on the northwestern coast of the municipality of Palompon, whose shoreline extends to about $26.32 \mathrm{~km}$. Additionally, averaging $1.4 \mathrm{~km}$ away from the shore, are three major islets namely: Tabuk, Gumalak, and Cabgan, collectively called Tres Marias (Figure 1). These three islets with sizes $0.47 \mathrm{~km}^{2}, 1.45 \mathrm{~km}^{2}$, and $0.32 \mathrm{~km}^{2}$, respectively, may influence the water circulation pattern in the area.

To identify the spatial variation of fishes caught in fish corrals that are distributed throughout the reef flat, the whole area was divided into four quadrats with main reference to the islet Cabgan,: Area $1\left(9.41 \mathrm{~km}^{2}\right)$, Area $2\left(14.45 \mathrm{~km}^{2}\right)$, Area $3\left(12.88 \mathrm{~km}^{2}\right)$, and Area $4\left(11.81 \mathrm{~m}^{2}\right)$. Reconnaissance of these areas was also done to characterize the substrates.

\section{The Palompon Fish Corral}

In Palompon, fish corrals are constructed from nylon nettings (polyamide) attached to bamboos and/or wooden stakes, which fits the description of Dugan et al. (2003) and similar to those in Virgin Islands (Jennings, 1990). The length and number of bamboos and wooden stakes used vary from one fish corral to another, with the distance between the 'leaders' or 'guides' ranging from $100 \mathrm{~m}$ to $200 \mathrm{~m}$, depending on the water depth and area where they are located. Moreover, the mesh size of the nets varies from one part of the gear to the other. The leader has a mesh size of $8 \mathrm{~mm}$, the playground has $9 \mathrm{~mm}$, and the bunt or catching chamber has a mesh size of $12 \mathrm{~mm}$ (Figure 2). These corrals are operated almost all throughout the year that involves maintenance, e.g. cleaning of nets and replacement of rotten or broken wooden stakes. 


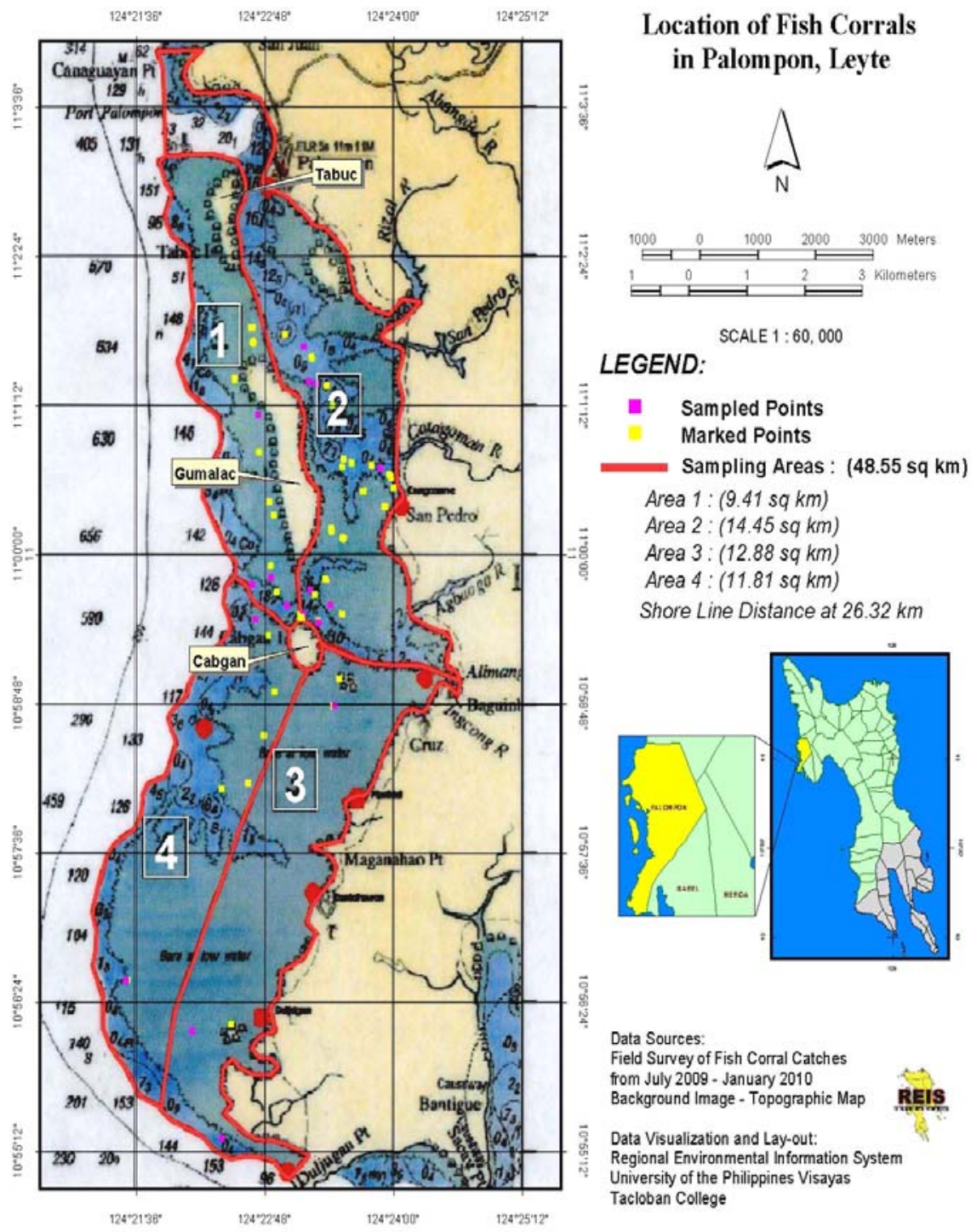

Figure 1. Map of Palompon reef flat with locations of sampled and marked fish corrals in the area. (Adapted from the on-going project Integrated Coastal Enhancement: Conservation, Research, Evaluation and Monitoring (ICE-CREAM)). 


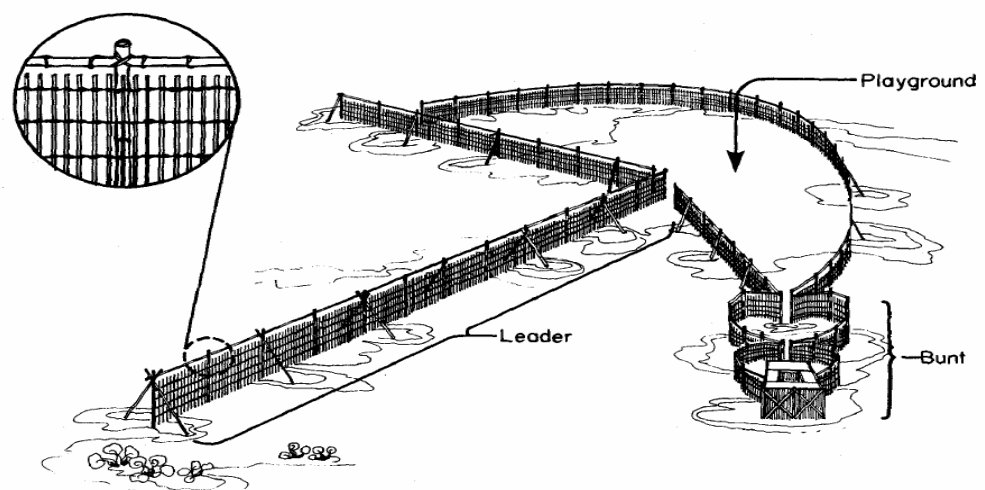

Figure 2. Fish corral (baklad). Source: Umali (1950).

There are 64 registered fish corral units in Palompon which are harvested everyday by one up to five persons. Harvesting is usually done early in the morning from $0600 \mathrm{H}$ to $0800 \mathrm{H}$, or late in the afternoon depending on the tide level at that particular part of the day.

\section{Data Collection}

The study utilized two sets of data from July 2009 to January 2010. The first set is the semi-monthly (i.e. with gap range of 10-20 days) field intercept samplings which were done mostly during the lowest tide level of the day. And the second set was taken from fish landing data, i.e. from all types of gear collected and recorded daily by field data enumerators from six randomly selected coastal barangays. The enumerators were contracted by the project Integrated Coastal Enhancement: Coastal Research, Evaluation and Adaptive Management (ICE-CREAM). However, only the fish corrals' data were used in this study.

\section{Intercept Sampling}

The semi-monthly intercept samplings sampled 27 fish corrals from July 2009 to January 2010, with an average of four fish corrals for each sampling. During samplings, fishermen who were harvesting their fish 
corrals were approached, and their total harvest either borrowed or bought. Total weight of the catch was recorded and fishes were sorted out according to species. Each fish was identified down to the species level, whenever possible, using field guide identification book of Masuda and Allen's Sea Fishes of the World (1987). Unidentified species were photographed, its meristic data gathered, and then identified in the laboratory using the Food and Agriculture Organization (FAO) Species Identification Guide for Fishery Purposes (2001). Morphometrics based on total and standard lengths as well as the fresh weight of each fish sample were measured. Weight ( $\mathrm{g}$ ) was measured using a battery operated digital weighing scale.

Sub-samplings were also done whenever the total catch exceeded the five-kilogram mark. Sub-samplings were done due to either lack of time in processing the sample on site or lack of financial logistics required to buy the entire catch. In such cases, only $20 \%$ of the total catch was taken as sample. Fish samples were processed in the laboratory for morphometric measurements.

\section{Fish Landed Data}

The enumerators were tasked to record the daily catch composition (using local names) and corresponding total weight ( $\mathrm{kg}$ ) of the fishes from fish corrals and other fishing gears in their barangays. The records were then encoded and summarized in Microsoft Office Excel spreadsheets. Fish families were determined from the local names upon verifications from both the enumerators and the fishers.

\section{Physico-chemical parameters}

Determination of the physico-chemical parameters was done during each sampling period to document the environmental conditions of the fishing area. These parameters include water depth, temperature, salinity, and $\mathrm{pH}$. Water depths $(\mathrm{cm})$ in every sampling station were measured at three different locations using a calibrated rope. Water temperature $\left({ }^{\circ} \mathrm{C}\right)$ was measured thrice (i.e. surface, middle, bottom) after immersing the $110^{\circ} \mathrm{C}$ mercury thermometer for three minutes. 
Water salinity was determined using an Atago handheld refractometer. For each sampling period, the instrument was calibrated using distilled water before taking the actual readings. The water on top of the prism and the surface of the daylight plate was patted gently using a tissue-like "Kimwipes". The same procedure for calibration was applied in measuring the salinity of seawater. This was also done three times for each sampling station.

Ajax Finechem $\mathrm{pH}$ paper was used in the determination of the $\mathrm{pH}$ of the water. The $\mathrm{pH}$ paper was dipped in the seawater sample and the resulting color change was compared to the standard $\mathrm{pH}$ paper color reference chart.

\section{Data Analyses}

The spatial and temporal diversity, evenness, and dominance of the fish species in the area were determined using Paleontological Statistics (PAST) version 1.40 software (Hammer et al., 2001). PAST is a freeware for the computation and derivation of different population indices.

\section{RESULTS AND DISCUSSION}

\section{Catch Composition}

Fishes caught from fish corrals in Palompon comprise a diverse fish assemblage that belongs to various families (Table 1). This was similarly observed by Mercene and Nasino (1994) in Laguna and Mangi et al. (2007) in Kenya. These findings could be attributed on the non-selectivity of the gear in trapping fishes (Dugan et al., 2003) that included both pelagic and demersal fishes. The presence of extensive seagrass beds, diverse algal species, and few reef areas provide as habitats for the diverse fish species. Rice and Gislason (1996) showed that species diversity, among others, is positively linked to the structural complexity of the substrate. 
Table 1. Relative weight of fish families using the intercept samplings from the reef flat of Palompon, Leyte, Philippines (Jul 2009 - Jan 2010).

\begin{tabular}{|c|c|c|c|c|c|}
\hline Family & $\begin{array}{c}\text { Total } \\
\text { Catch }(\mathrm{Kg}) \\
\end{array}$ & $\begin{array}{c}\% \text { Relative } \\
\text { Weight }\end{array}$ & Family & $\begin{array}{c}\text { Total } \\
\text { Catch }(\mathrm{Kg})\end{array}$ & $\begin{array}{c}\% \text { Relative } \\
\text { Weight }\end{array}$ \\
\hline Siganidae & 11.01 & 46.08 & Scaridae & 0.19 & 0.80 \\
\hline Clupeidae & 1.54 & 6.43 & Lutjanidae & 0.15 & 0.63 \\
\hline Tetraodontidae & 1.32 & 5.51 & Scorpidinae & 0.15 & 0.62 \\
\hline Apogonidae & 1.28 & 5.36 & Nemipteridae & 0.12 & 0.50 \\
\hline Gerreidae & 1.02 & 4.27 & Monacanthidae & 0.11 & 0.45 \\
\hline Atherinidae & 0.97 & 4.05 & Synodontidae & 0.10 & 0.40 \\
\hline Pomacentridae & 0.88 & 3.65 & Ephippidae & 0.05 & 0.19 \\
\hline Carangidae & 0.82 & 3.43 & Fistulariidae & 0.05 & 0.21 \\
\hline Mullidae & 0.77 & 3.20 & Tetrarogidae & 0.05 & 0.22 \\
\hline Lethrinidae & 0.70 & 2.91 & Centriscidae & 0.04 & 0.15 \\
\hline Labridae & 0.64 & 2.67 & Holocentridae & 0.04 & 0.15 \\
\hline Engraulidae & 0.53 & 2.16 & Terapontidae & 0.03 & 0.11 \\
\hline Sphyraenidae & 0.53 & 2.20 & Acanthuridae & 0.02 & 0.06 \\
\hline Plotosidae & 0.31 & 1.28 & Ophichthidae & 0.02 & 0.08 \\
\hline Leiognathidae & 0.27 & 1.11 & Pinguipedidae & 0.01 & 0.06 \\
\hline Belonidae & 0.25 & 1.05 & & & \\
\hline
\end{tabular}

During the seven-month period of intercept samplings, 27 fish corral gear units were sampled that recorded 2,245 fishes. An average of about $4.07 \pm 1.74 \mathrm{~kg}$ of fish per day for each fish corral unit was estimated. Table 1 shows the fish families encountered during the intercept samplings and their corresponding contribution. The top five fish families accounted $67.65 \%$ of the $23.97 \mathrm{~kg}$ total weight. Family Siganidae (Rabbitfishes) had the highest relative weight of $46.08 \%$, followed by families Clupeidae, Tetraodontidae, Apogonidae, and Gerreidae which accounted $21.57 \%$ of the total weight.

Robinson et al. (2004) similarly observed that the most commonly caught fishes by fish corrals in Seychelles include economically important fish groups such as rabbitfishes. Siganids are diurnal herbivores that progressively feed on zoo- and phytoplankton as larvae, fine algae as small juveniles, and coarse seaweeds, encrusting algae, and occasionally sea grasses, as adults (Nelson, 1984; Woodland, 2001b).

Family Clupeidae (sardines and herrings) is mostly planktivorous. However, their preference for coastal and schooling mode of life (Whitehead, 1985) probably led to their high collective weight, 
consequently increasing the relative importance value. These reasons may not apply to the Fam. Tetraodontidae (pufferfishes) except from the fact that the group prefers shallow nearshore waters (Shipp, 2001). Similar to the siganids, most cardinalfishes (Fam. Apogonidae) also has high preference for seagrasses (Allen, 2001). Lastly, just like the clupeids, Gerreidae (mojarras) is also a schooling family (Woodland, 2001a).

The above finding was collaborated by the enumerators' data in that Fam. Siganidae dominated the catch composition accounting for $46 \%$ relative weight (see Figure 3). Like in the intercept samplings, Families Apogonidae and Gerreidae also came out as among the top five ranking families, i.e. both having $2 \%$ relative weight.

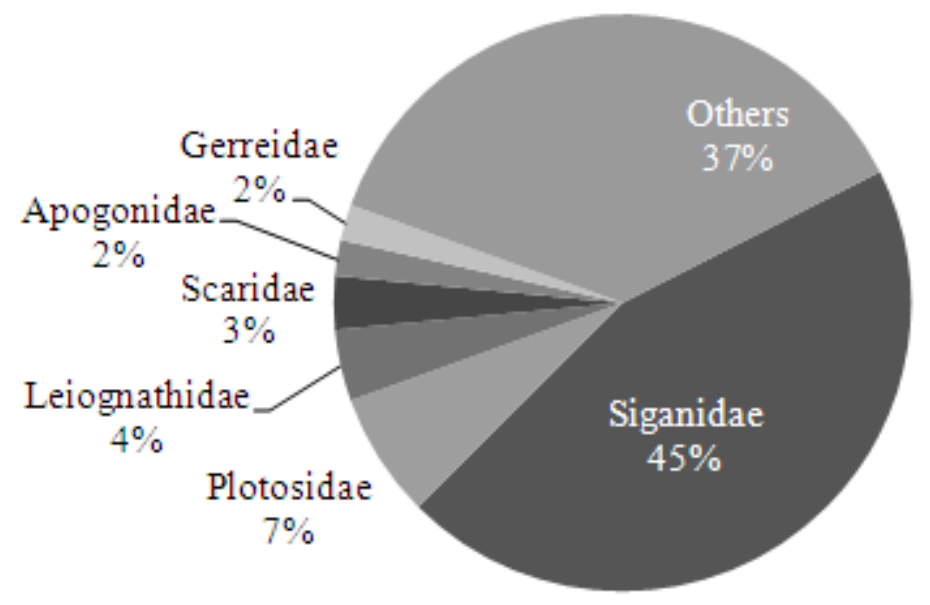

Figure 3. Fish catch composition (by weight) based on fish landed data (Aug 2009 - Jan 2010).

On the species level, combined catch from the intercept samplings was dominated by Siganus canaliculatus, Arothron nigropunctatus, Amblygaster sirm, Atherinomorus lacunosus, and Selar crumenopthalmus (Fig. 4), in which, if combined, comprised $52 \%$ of the total catch. The remaining 77 species comprised the other $48 \%$. 


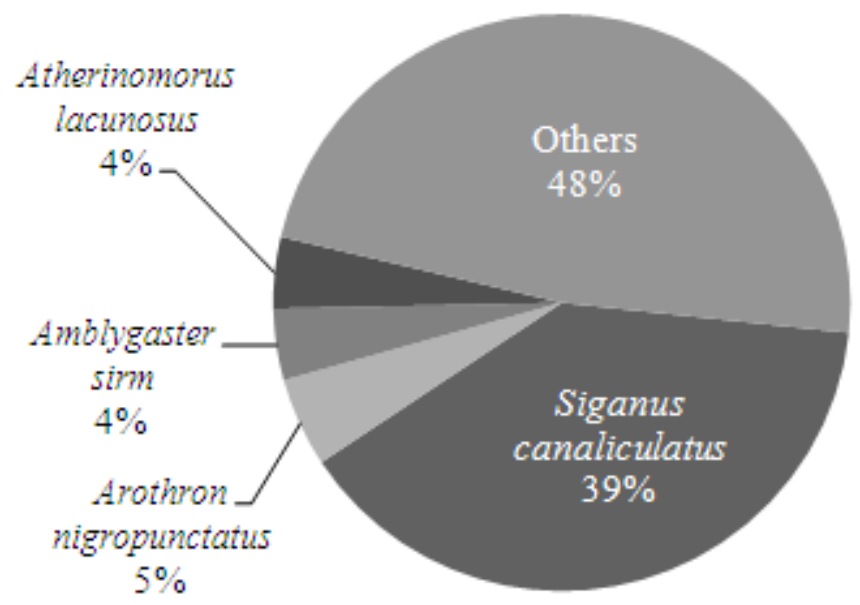

Figure 4. Percentage species composition (by weight) of fishes caught in fish corrals using intercept samplings (Jul 2009 - Jan 2010).

\section{Species Diversity and Seasonal Abundance}

From the 2,245 fish samples collected, 31 families, 47 genera, and 81 species were identified. The various indices as computed by the PAST software, are shown in Table 2. This included the species richness, temporal dominance, diversity, and evenness of the fish samples. The indeces varied among months indicating seasonality of the fishes in Palompon.

Table 2. Diversity indices according to species' temporal distribution (Jul 2009 Jan 2010).

Sampling Period

\begin{tabular}{rccccccc} 
& Jul-09 & Aug-09 & Sep-09 & Oct-09 & Nov-09 & Dec-09 & Jan-09 \\
\hline Species Richness & 40 & 14 & 4 & 27 & 25 & 9 & 30 \\
Dominance, D & 0.18 & 0.43 & 0.97 & 0.26 & 0.19 & 0.87 & 0.13 \\
Shannon, H & 2.52 & 1.23 & 0.10 & 2.16 & 2.18 & 0.35 & 2.44 \\
Simpson, 1-D & 0.82 & 0.57 & 0.03 & 0.74 & 0.81 & 0.13 & 0.87 \\
Evenness, $\mathrm{e}^{\wedge} \mathrm{H} / \mathrm{S}$ & 0.31 & 0.24 & 0.28 & 0.32 & 0.37 & 0.16 & 0.40
\end{tabular}


Figure 5 shows the monthly abundance of the three dominant families. Siganidae was most abundant in December and least during September. On the other hand, the families Pomacentridae and Apogonidae were abundant during September and August, respectively.

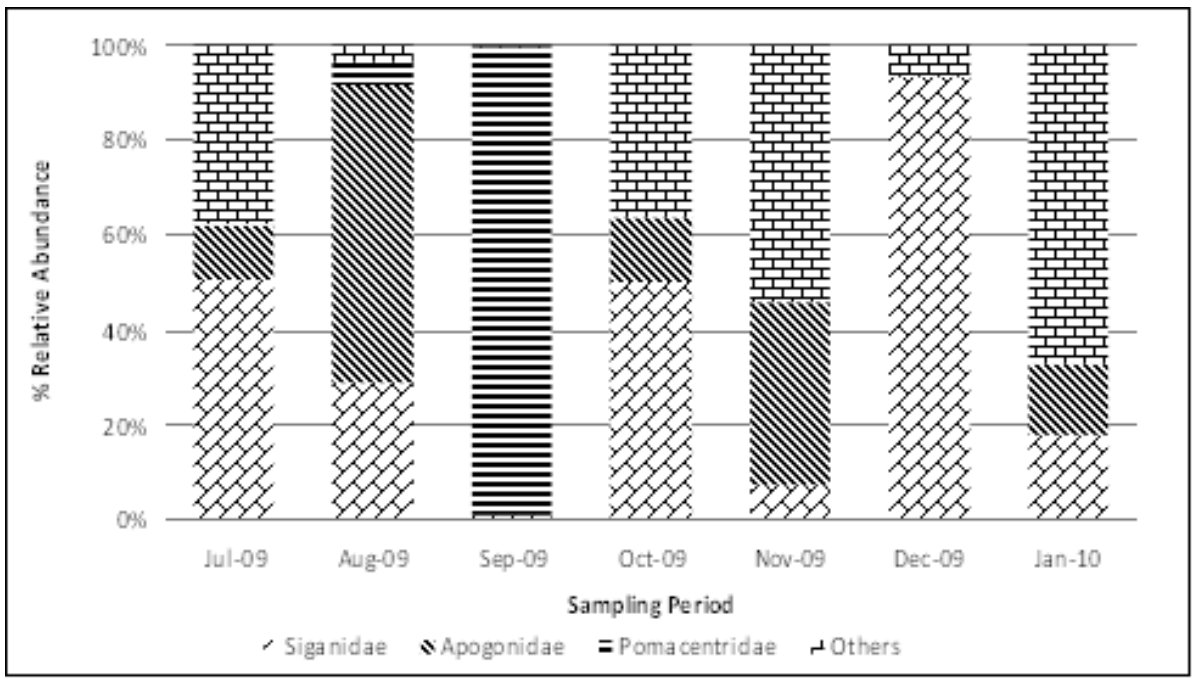

Figure 5. The relative abundance of the three most dominant families caught by the fish corrals in Palompon during field intercept samplings (Jul 2009 - Jan 2010).

The trend of abundance for families Siganidae and Apogonidae was similarly observed in the fish landing data (Fig. 6). Figure 7 shows the monthly abundance of the top species. Siganus canaliculatus was abundant in July, October, and December; whereas, Apogon gilberti was abundant in August and November; and Chromis viridis in September.

\section{Spatial Distribution}

The fishes were widely distributed in the whole reef flat of Palompon. Variation in composition of the caught fishes in these gears depended on the characteristic of the environment where the gears were located. Reef fishes exhibit territorial behavior that is extremely affected by the characteristics of their habitat (Pereira, 2000). 


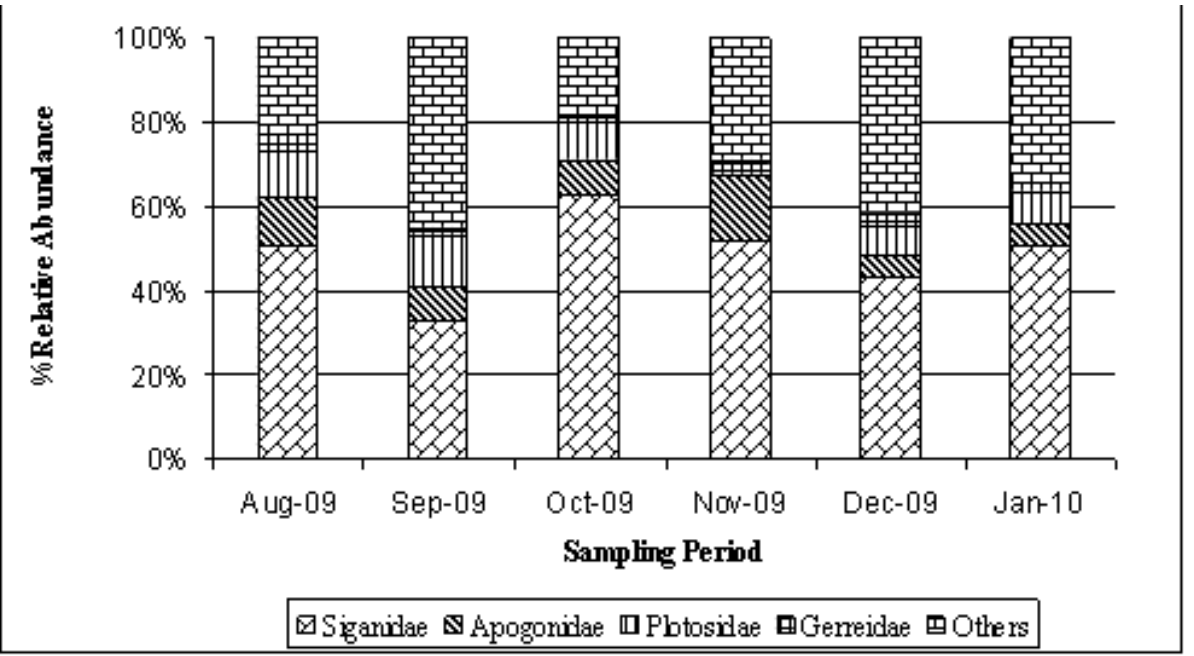

Figure 6. Relative abundance of the top four fish families from the fish landing data (Aug 2009 to Jan 2010).

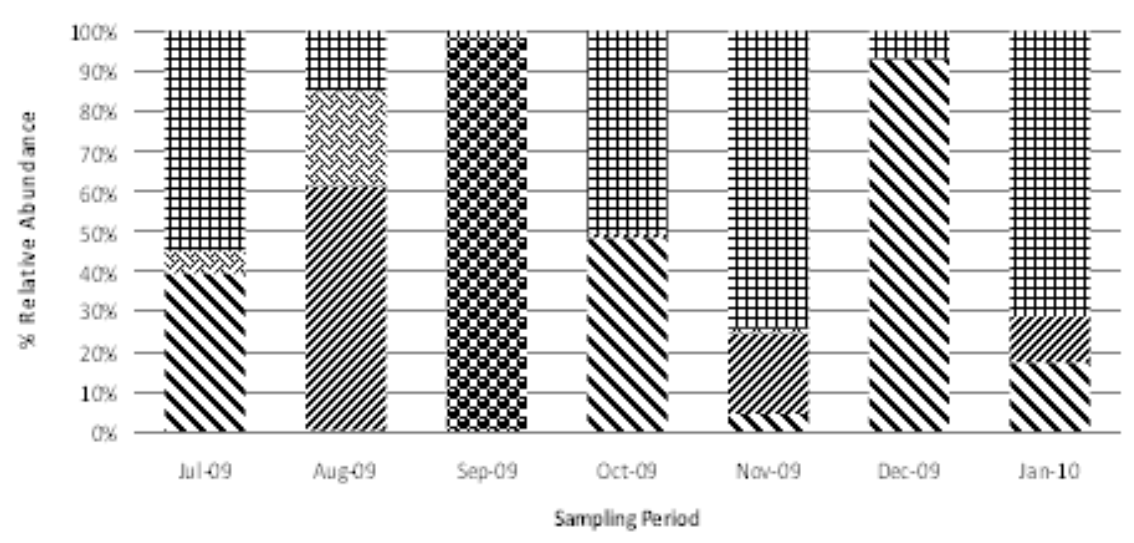

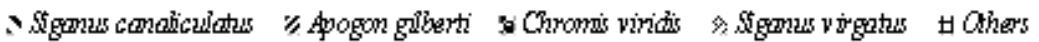

Figure 7. Relative abundance of the dominant species in Palompon reef flat using intercept sampling (Jul 2009 - Jan 2010). 
Figure 8 shows the difference in the quantity of fishes caught in the four sampling areas. Area 2, located at the northeastern section of the reef flat (refer to Fig. 1), had the highest number of fish samples caught, and Area 4 had the least number of fish samples caught.

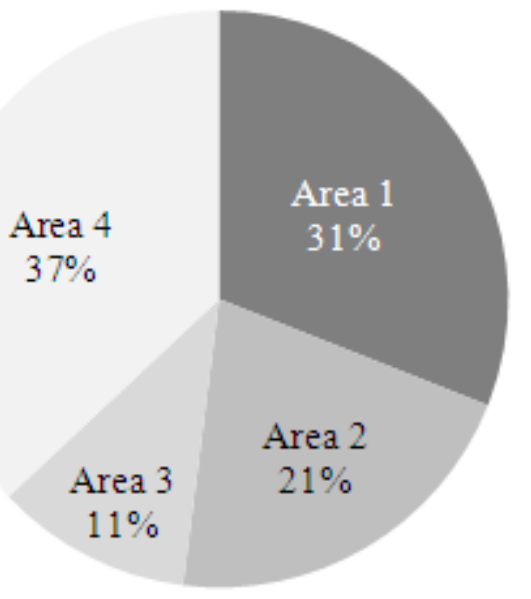

Figure 8. Area-wise catch contribution to the total fish weight surveyed using intercept samplings in the Palompon reef flat (Jul 2009 - Jan 2010).

The spatial distribution of fish species varied across the sampling areas. Siganus canaliculatus was found in Areas 1 and 2 and was primarily caught in Area 2. On the other hand, Apogon gilberti was well distributed in Area 1 and together with Atherinomorus lacunosus and Engraulis japonicus in Area 3. Chromis viridis was caught in Area 2 as Arothron nigropunctatus was in Area 4 (Figure 9).

Table 3 shows indices of species richness, dominance, diversity, and evenness among areas. Area 2 had the highest species diversity compared to the other areas. Area 1 had the highest index of dominance, whereas Area 4 had the highest index of evenness, but lowest in dominance and diversity.

Data showed an unequal distribution of reef fishes (as well as fish corrals) in the four identified sampling areas in the reef flat. Area 2 had the most of the samples caught, while Area 4 had the least. The unequal distribution of reef fishes could be due to the physical characteristics of the areas. Fish corrals are usually constructed across water canals where 


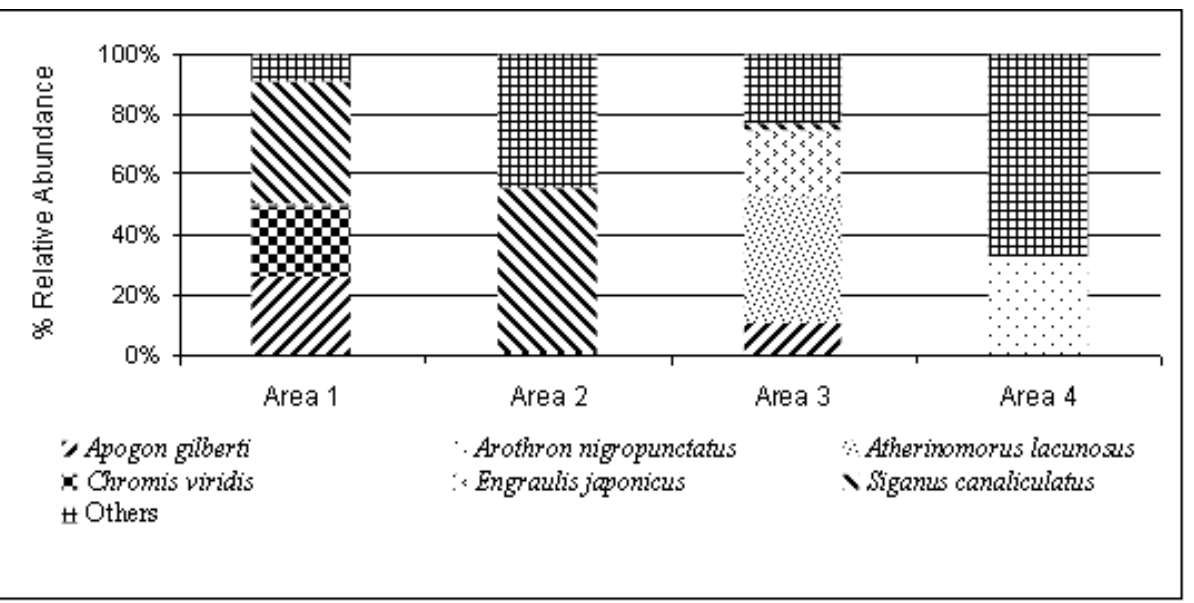

Figure 9. Spatial distribution of the major species caught in the Palompon reef flat (Jul 2009 - Jan 2010).

Table 3. Diversity indices according to species' spatial distribution (Jul 2009 - Jan 2010).

\begin{tabular}{rcccc} 
& \multicolumn{5}{c}{ Areas } \\
\cline { 2 - 5 } & Area 1 & Area 2 & Area 3 & Area 4 \\
\hline Species Richness & 30 & 49 & 19 & 6 \\
Dominance, D & 0.29 & 0.21 & 0.19 & 0.18 \\
Shannon, H & 1.56 & 2.49 & 2.24 & 1.94 \\
Simpson, 1-D & 0.71 & 0.79 & 0.81 & 0.82 \\
Evenness, $\mathrm{e}^{\wedge} \mathrm{H} / \mathrm{S}$ & 0.16 & 0.21 & 0.34 & 0.70
\end{tabular}

most of the fishes migrate. Areas 1 and 2 have numerous water canals making fish corrals effective in catching fishes in these areas. Areas 3 and 4 are too shallow to be exposed during low tides rendering the gear inefficient to catch fish. This explains for the small number of fish corrals found in Areas 3 and 4. Moreover, Areas 1 and 2 had more varied habitat than Areas 3 and 4. The substrate of the latter was mostly sandy with a few patches of seagrass, seaweeds and algae. On the other hand, Areas 1 and 2 had extensive seagrass, seaweeds, algal beds, and coral reefs with lagoon. These areas served as nursery grounds for the fishes.

The catch composition of fish corrals in Areas 1 and 2 did not greatly differ from each other, with Siganus canaliculatus and Apogon gilberti as abundant species. This indicates that the presence of the two larger 
islets do not pose as barrier to affect the species composition in the two areas. One possible reason for this is that water circulation seems to feed both areas with relatively the same species. Also, the water dynamics in these areas seem to favor the species to move about from Area 1 to Area 2 and vice versa. It was also observed that fishes caught in Areas 1 and 2 differed from those caught in Areas 3 and 4, wherein the dominant species were either absent or present in small quantities. The difference in catch composition among the areas could be due to the presence of diverse habitat, specifically the presence of extensive seagrass beds, in Areas 1 and 2 than of Areas 3 and 4.

Diversity, dominance, and evenness also differed among the sampling areas (Table 3 ). Area 2 had the highest species diversity compared to the other areas. This is because this area had the most number of the samples caught. In fact, of the four areas, Area 2 has the highest number of samples with 1187 individuals. Moreover, dominance and evenness of samples in the area were relatively equal to each other, indicating no significant difference in the abundance of the different species found in this area.

On the other hand, the low evenness value for Area 1 was compensated by a high dominance value which indicated that certain species (e.g. Siganus canaliculatus) were dominant during the sampling periods. In contrast, the high evenness value in Area 4 was compensated by the low dominance value. This shows the inverse relationship of dominance and evenness, i.e. as the dominance increases, evenness decreases and vice versa.

\section{Temporal Variation}

The indices on dominance, diversity, and evenness varied among fish samples among months (Table 2). July samples had the highest species diversity among months but low in dominance, indicating that the abundance of the fishes during July was relatively the same. September sample, in contrast, had the highest value in dominance but lowest in species diversity. This result could be mainly due to the only four fish species that included Plotosus lineatus, Siganus guttatus, Siganus spinus, with Chromis viridis occupying $97 \%$ of the total catch. 
In general, the presence of southwesterly (May to October) and northeasterly (November to April) winds could have influenced the fish seasonality of the area (Soliman et al., 2008). These wind patterns affect water circulation of an area that influencet abundance, diversity, seasonality, dominance, and evenness of the fishes. In addition, southwest monsoon is characterized by a high amount of precipitation, which allows thorough mixing of the water column, thus resulting in lower salinity. On the other hand, the northeast monsoon is characterized by a low rainfall and discharge, thus resulting in the increase of water salinity (MacClanahan, 1988). Such changes in water parameters could result to the increase or decrease in other marine organisms, and in turn may influence the availability of other food sources in the area. However, results shown in Figure 5 indicate that not all of the fish families were affected by the change in seasons. Siganus canaliculatus had high relative abundance throughout the study period. This is because of the euryhalic and eurythermic characteristics of rabbitfishes (Saoud et al., 2007). Another reason that could account for this is the aggregation of these fishes for spawning purposes. In such periods, there could be a three-fold increase in the density among rabbitfishes (Domeier and Colin, 1997).

The cardinalfishes (Apogonidae) are the second most widely caught fishes after rabbitfishes. They were consistently present except in February; although their density was relatively small compared to that of rabbitfishes. Family Apogonidae had shown to be the most diverse with 13 species. However, despite their high abundance, they are the least taxa. Information concerning their biology and ecology is limited (Williams, 1991; Munday and Jones, 1998; Marnane and Bellwood, 2002). Some studies have noted that a number of apogon species exhibit strong fidelity to the same resting sites (Marnane, 2000), suggesting that specific features of the habitat may be important. However, the degree of habitat specificity and niche partitioning at this scale has not been examined for this group.

Pomacentridae, represented by Chromis viridis, was abundant during September. It is inconclusive to say that this species was the most dominant during the month due to lack of data gathered since only one fish corral was sampled in this period. Moreover, the enumerator's data does not support this observation since most of the species landed were of economic 
importance. Chromis viridis is a non-economic species usually found in large aggregations above branching corals like Acropora spp. as well as in sheltered areas such as subtidal reef flats and lagoons (Lieske and Myers, 1994). It was also observed that different months were dominated by different species thereby making it difficult to ascertain the seasonality of these species.

\section{Physicochemical Parameters}

There was no significant difference in physicochemical parameters of the waters among months at Palompon, Leyte during the study (Table 4). The water temperature recorded in the area had an average of $28.53^{\circ} \mathrm{C}$ \pm 1.31 . The highest water temperature was recorded during the months of September and October, both having an average of $30^{\circ} \mathrm{C}$; whereas the lowest temperature was in December with $27^{\circ} \mathrm{C}$. The average water salinity in the area was $35.58 \mathrm{ppt} \pm 3.17$. Furthermore, the highest water salinity was recorded in December (39 ppt), while the lowest was in October (32.17 ppt). The $\mathrm{pH}$ was slightly basic, with an average of $7.42 \pm 0.49$.

Table 4. The physicochemical parameters of waters in Palompon, Leyte (Aug 2009 - Jan 2010).

\begin{tabular}{|c|c|c|c|c|c|c|c|c|}
\hline \multirow{2}{*}{$\begin{aligned} & \text { Month } \\
& \text { Jul } 2009\end{aligned}$} & \multicolumn{2}{|c|}{ Ave. Temperature $\left({ }^{\circ} \mathrm{C}\right)$} & \multicolumn{3}{|c|}{ Ave. Salinity (ppt) } & \multicolumn{3}{|c|}{ Ave. $\mathrm{pH}$} \\
\hline & \multicolumn{2}{|c|}{-} & \multicolumn{3}{|c|}{ - } & \multicolumn{3}{|c|}{ - } \\
\hline Aug 2009 & 29.0 & 0.05 & 33.0 & \pm & 0.10 & 7.50 & \pm & 0.07 \\
\hline Sep 2009 & 30.0 & 0.04 & 33.0 & \pm & 0.10 & 8.00 & \pm & 0.06 \\
\hline Oct 2009 & 30.0 & 0.04 & 32.2 & \pm & 0.10 & 8.00 & \pm & 0.06 \\
\hline Nov 2009 & 27.6 & \pm 0.05 & 37.9 & \pm & 0.08 & 7.00 & \pm & 0.07 \\
\hline Dec 2009 & 27.0 & 0.05 & 39.0 & \pm & 0.08 & 7.00 & \pm & 0.07 \\
\hline $\operatorname{Jan} 2010$ & 27.6 & $\pm \quad 0.05$ & 38.4 & \pm & 0.08 & 7.00 & \pm & 0.07 \\
\hline Average & \multicolumn{2}{|c|}{28.5} & \multicolumn{3}{|c|}{35.6} & \multicolumn{3}{|c|}{7.42} \\
\hline Std. Dev. & \multicolumn{2}{|r|}{1.31} & \multicolumn{3}{|c|}{3.17} & \multicolumn{3}{|c|}{0.49} \\
\hline
\end{tabular}


All these parameters were inconclusive in explaining the seasonal variations in the fish catch. Albeit the data have established that any fish caught during these specific times can definitely tolerate the values observed.

Direct comparison cannot be established between the four sampling areas in terms of the physicochemical parameters since the study failed to take measurements from all the four areas during each and every sampling. These failures were caused by the very nature of the intercept survey, i.e. only corrals being harvested were approached, and sometimes the failure of the GPS receiving device to take accurate coordinates readings, e.g. due to cloud cover.

\section{CONCLUSION}

Fish corrals in Palompon, Leyte catch a diverse fish assemblage from various fish families. Because of its non-selectivity, it catches both large and small fishes, both pelagic and demersal ones. However, the temporal and spatial distributions of these species vary from one another. Temporal or seasonal variation might have been caused by the monsoons and their consequential effects like freshwater influx and variation in water circulation within the reef flat. The difference in the number of habitats available among the sampling areas contributed to the variation in the spatial composition and distribution of the different species.

Despite the diversity of fishes caught using fish corral, seasonality on the kind of fishes caught was observed. Data from intercept samplings and daily landings indicate that the most abundant species caught in the reef flat were the rabbitfishes (Fam. Siganidae), whose relative abundance was high throughout the study period. It was followed by the cardinal fishes (Fam. Apogonidae). The seasonality of these two groups of fishes differed from one another. Intercept sampling data indicated that the rabbitfishes were most abundant during the months of July, October, and December, but were also abundant during August, September, and January. Whereas, the cardinal fishes were most abundant in August and November. The seasonality of other fish families could hardly be established since certain different fish families dominate in different months. 
The spatial distribution data indicate differences in the catch composition and quantity of the fishes caught among the sampling areas. Of the four sampling areas, Area 2, located in the northeastern part of the reef flat, had the highest abundance and diversified fishes caught. Area 2 had the most number of fish corrals where extensive seagrass and algal beds interspaced with coral patches exist. Area 4, located at the southwestern of the flat, characterized by a sandy substrate with patches of seagrass and algae, had the least number of fishes caught. The physicochemical parameters did not vary much temporally, were well within the normal range of values expected in tropical reef flat environment, but failed to fully explain variations in fish catch.

\section{ACKNOWLEDGMENT}

The authors wish to thank Dr. Wilfredo L. Campos, Project Leader for the Integrated Coastal Enhancement: Coastal Research, Evaluation and Adaptive Management (ICE-CREAM) Project 4 Title: Coastal Ecosystem Science, Research and Monitoring: Fisheries Ecosystem Connectivity and Monitoring (Fish EConnect) for the trust he afforded the group.

\section{REFERENCES}

ALLEN, G. R. 2001. Apogonidae. In: FAO species identification guide for fishery purposes. The Living Marine Resources of the Western Central Pacific. Volume 6. Bony Fishes Part 4 (Labridae to Latimeriidae), Estuarine Crocodiles, Sea Turtles, Sea Snakes and Marine Mammals (K. E. Carpenter and V. H. Niem, eds). FAO, Rome. pp. 2602-2613.

CALUD, A., G. RODRIGUEZ, R. ARUELO, G. AGUILAR, E. CINCO, N. ARMADA, and G. SILVESTRE. 1989. Preliminary results of a study of the municipal fisheries in Lingayen Gulf. p. 3-29. In: 
Towards sustainable development of the coastal resources of Lingayen Gulf, Philippines (G. Silvestre, E. Miclat, and T.-E. Chua, eds). ICLARM Conf. Proc. 17, 200 p. PCAMRD, Los Baños, Laguna, and ICLARM, Makati, Metro Manila, Philippines.

DUGAN, C. E., A. L. BERNARTE, and C. A. VERA, JR. 2003. Guide to fishing gears in the Philippines. SIKAT Inc. Quezon City. 328p.

DOMEIER, M. L. and P. L. COLIN. 1997. Tropical reef fish spawning aggregations: defined and reviewed. Bull Mar. Scie. 60:698-726.

JENNINGS, C. A. 1990. Use of fish corrals in the seine fishery of the Virgin Islands. Marine Fisheries Review 52(3).

HAMMER, Ø., D. A. T. HARPER, and P. D. RYAN. 2001. PAST: Paleontological Statistics Software Package for Education and Data Analysis. Palaeontologia Electronica 4(1):9pp.

LIESKE, E. and R. MYERS. 1994. Collins Pocket Guide. Coral reef fishes. Indo-Pacific \& Caribbean including the Red Sea. Harper Collins Publishers. $400 \mathrm{p}$.

MANEJA, R. H. and V. V. HILOMEN. 2008. Spatial and temporal patterns of distribution of major fish species and catch rates of three fishing gears in Bolinao, Pangasinan. University of the Philippines Journal of Natural Sciences 13:55-70.

MANGI, S. C., C. M. ROBERTS, and L. D. ROODWELL. 2007. Financial comparisons of fishing gear used in Kenya's coral reef lagoons. Ambio 36(8).

MARNANE, M. J. 2000. Site fidelity and homing behaviour in coral reef cardinalfishes. J Fish Biol 57:1590-1600.

MARNANE, M. J. and D. R. BELLWOOD. 2002. Diet and nocturnal 
foraging in cardinalfishes (Apogonidae) at One Tree Reef, Great Barrier Reef, Australia. Mar Ecol Prog Ser 231:261-268.

MASUDA, H. and G. R. ALLEN. 1987. Sea Fishes of the World. 528pp. YAMA-KEI Publ. Co. Ltd., Tokyo. (Body Text In Japanese; Scientific Name in English and Japanese.)

MCCLANAHAN, T. R. 1988. Seasonality of East Africa's coastal waters. Marine Ecology Progress Series 44:191-199.

MERCENE, E. C. and M. P. NASINO. 1994. An assessment of the goby fishery in Laguna de Bay, Philippines. Asia Life Sciences. 3(1):2534.

MUNDAY, P. L. and G. P. JONES. 1998. The ecological implications of small body size among coral-reef fishes. Oceanogr Mar Biol Annu Rev 36:373-411.

NELSON, J. S. 1984. Fishes of the world. 2nd edition. John Wiley \& Sons, Inc., New York. 523 p.

PEREIRA, A. M. 2000. A review on the ecology, exploitation, and conservation of reef fish resources in Mozambique. Presented at the 2nd National Conference on Coastal Zone Research, Naputo. pp. 27-29

RICE, J. and H. GISLASON. 1996. Patterns of change in size spectra of numbers and diversity of the North Sea fish assemblage, as reflected in surveys and models. ICES Journal of Marine Science 53:12141225

ROBINSON, J., M. ISIDORE, M. A. MARGUERITE, M. C. OHMAN, and R. J. PAYET. 2004. Spatial and temporal distribution of reef fish spawning aggregations in the Seychelles-An interview-based survey of artisanal fishers. Western Indian Ocean Journal of 
Marine Science 3(1):63-69.

SAOUD, I. P., S. KREYDIYYEH, A. CHALFOUN, and M. FAKIH. 2007. Influence of salinity on survival, growth, plasma osmolality and gill $\mathrm{Na}^{+}-\mathrm{K}^{+}$-ATPase activity in the rabbitfish Siganus rivulatus. Journal of Experimental Marine Biology and Ecology 348:183190.

SHIPP, R. L. 2001. TETRAODONTIDAE: Puffers. In: FAO species identification guide for fishery purposes. The Living Marine Resources of the Western Central Pacific. Volume 6. Bony Fishes Part 4 (Labridae to Latimeriidae), Estuarine Crocodiles, Sea Turtles, Sea Snakes and Marine Mammals (K. E. Carpenter, V. H. Niem, eds). Rome, FAO. 2001. pp 1988-1998.

SOLIMAN, V. S., A. B. MENDOZA, and K. YAMAOKA. 2008. Seaweed-associated fishes of Lagonoy Gulf in Bicol, the Philippines—with emphasis on siganids (Teleoptei: Siganidae)— Kuroshio Science 2(1):67-72.

SUPANGA, N. C. and I. R. SMITH. 1994. Costs and returns of Cabusao stationary gears, p. 45-60. In: Small-scale fisheries of San Miguel Bay, Philippines: economics of production and marketing (I.R. Smith and Mines, eds). ICLARM Technical Reports pp. 8, 143.

UMALI, A. F. 1950. Guide to the Classification of Fishing Gear in the Philippines. Washington, U. S. Govt. Print. Off. pp. 165.

WHITEHEAD, P. J. P. 1985. FAO Species Catalogue. Vol. 7. Clupeoid fishes of the world (suborder Clupeioidei). An annotated and illustrated catalogue of the herrings, sardines, pilchards, sprats, shads, anchovies and wolf-herrings. Part 1 - Chirocentridae, Clupeidae and Pristigasteridae. FAO Fish. Synop. 125(7/1):1-303.

WILLIAMS, D. M. 1991. Patterns and processes in the distribution of 
coral reef fishes. In: The Ecology of Fishes on Coral Reefs (P. F. Sale, ed). Academic Press, San Diego, CA, pp. 437-474.

WOODLAND, D. J. 2001b. Siganidae. In: FAO species identification guide for fishery purposes. The Living Marine Resources of the Western Central Pacific. Volume 6. Bony Fishes Part 4 (Labridae to Latimeriidae), Estuarine Crocodiles, Sea Turtles, Sea Snakes and Marine Mammals (K. E. Carpenter and V. H. Niem, eds). Rome, FAO. 2001. pp. 3627-3641.

WOODLAND, D. J. 2001a. GERREIDAE Mojarras (silverbiddies). In: FAO species identification guide for fishery purposes. The Living Marine Resources of the Western Central Pacific. Volume 6. Bony Fishes Part 4 (Labridae to Latimeriidae), Estuarine Crocodiles, Sea Turtles, Sea Snakes and Marine Mammals (K. E. Carpenter and V. H. Niem, eds). Rome, FAO. 2001. pp. 2946 - 2954. 